\title{
Modernization of academic mobility in the period of digitalization of education
}

\author{
Vladimir Sulimin ${ }^{1}$, Vladislav Shvedov ${ }^{1}$, Maya Lvova ${ }^{1, *}$ \\ ${ }^{1}$ Ural State University of Economics, 62, 8 marta street, 620144, Yekaterinburg, Russia
}

\begin{abstract}
The issue of academic mobility is one of the most important global challenges during the digitalization of education. In particular, it is important to identify methods and tools that meet international requirements. The issue of increasing the effectiveness of the organizational mechanism of academic mobility is acute in the law "On Education in the Russian Federation." The main goal is to increase academic mobility and efficiency of mobility in the labor market. The article analyzes the state of development of academic mobility, defines the essence of this period, identifies the types and objectives of academic mobility. The author considers the weaknesses of the documents regulating the problem of academic mobility. The article substantiates the necessity and expediency of the development of academic mobility in terms of the impact on the country's economy, and in terms of improving the quality of education.
\end{abstract}

\section{Introduction}

The introduction of digitalization technologies for education provides for the reform of the organizational and methodological management systems of higher education in order to achieve national educational policy goals. The European direction of development of higher education requires the organization of events by the central authorities of higher education. The activities are aimed at supporting the implementation of key provisions: ensuring a high level of quality of higher education and promoting the mobility of university subjects through interstate recognition of qualifications and their profiles. Russian scientists E.A. Ivanchenko, A.V. Rzhevska, M.G.Yaytsenko, and others were studying certain aspects of academic mobility. The study of the essence of the academic mobility process has been the subject of a study of a wide field of foreign scientists: B. Wächter, U. Tayhler, L. Pūrser, C. Schnelleo, S. Garben. Issues of state management of higher education reform processes, it should be noted, are insufficiently studied and require further study.

\section{Material and methods}

At the present stage of reforming the higher education system in the context of implementing the provisions, an important challenge is the implementation of standards, recommendations, and basic tools that promote compatibility, comparability, recognition of periods and periods for training (training) specialists [1, 5]: the introduction of the national qualifications framework (NQF); European Credit Transfer and Accumulation
System (ECTS) and the Diploma Supplement, the introduction of the tricycle system (bachelor, master, $\mathrm{PhD}$ ) and the competence-based approach in education.

The relevance of the above activities, included in the content of the process of modernization of the organizational and methodological mechanism of management of higher education, is determined at the legislative level. Tasks are highlighted in such documents as the Law "On Education in the Russian Federation" [2], the Strategy for Economic and Social Development of Russia [8]. These steps are inseparably linked with each other and with mobility issues. Mobility refers to the prerequisites of mobility on the part of the student (language skills, financial viability), and the institutional ability to accept foreign students and send their students to study in educational institutions in other countries.

The definition of academic mobility given in the Law of Russia "On Education in the Russian Federation" is theoretically important for research. Academic mobility is the opportunity for participants in the educational process to study, teach, train or conduct research activities at another institution of higher education (scientific institution) in Russia or abroad [2]. Mobility is not only an opportunity but first of all its realization by certain subjects of the educational process at conditions. The efficiency of modernization of the organizational and methodological mechanism can be one of such conditions. There are documents of the supranational level necessary for understanding the essence of academic mobility, its principles, and implementation tools. However, they include only general principles, approaches, and values at the national level. Therefore, the development of mobility issues is a matter for each individual country and is inextricably linked with state policy and the strategy for

\footnotetext{
$\overline{{ }^{*} \text { Corresponding author: lvova usue@mail.ru }}$
} 
the development of higher education, which is based on state goals.

The problem of student and teacher mobility is not regulated by one special act in Russia. There are a number of documents that are different in status and the body that issued them from the National Strategy in bilateral agreements in the field of education between countries.

\section{Result and discussions}

The Law of Russia "On Education in the Russian Federation" defines the powers of the central executive body in the field of education and science, and other bodies. In the field of management, there are higher educational institutions that regulate mobility issues, the rights of applicants of higher education who implement the right to academic mobility, measures to support academic mobility and some other aspects [2]. According to the National Strategy for the Development of Education for 2012-2021, international cooperation in the field of education is intended to ensure the integration of the national education system into the international educational space. It provides for: the conclusion with other states and the implementation of intergovernmental and interdepartmental agreements on cooperation in the field of education and science; organizing educational and scientific exchanges, internships, and studying abroad for students, pedagogical and scientific-pedagogical workers; increasing the participation of educational institutions, teachers, scientists, and students in various projects and programs of international organizations and communities (Tempus, Erasmus Mundus, Jean Monet, and others); training of foreign citizens and stateless persons in higher educational institutions of Russia [5].

In addition to the above, there are documents that regulate certain aspects of mobility. Thus, measures to support the incoming and outgoing mobility of students are spelled out in the order "On approval of the plan of measures for the development of higher education for the period up to 2020". The document provides for the development and implementation of measures to attract foreign students to study in Russia. It provides for an increase in the number of curricula in higher education and postgraduate education institutions; and education at higher educational institutions of the divisions of international academic mobility, taking into account the need to join higher education institutions of Russia in the International Network of Agencies for Quality Assurance of Higher Education [7]. Considering the urgent need for cooperation of higher educational institutions and scientific institutions of Russia with leading higher educational institutions and scientific institutions abroad, Resolution No. 411 "Issues of student education and internships for postgraduate students, scientific and pedagogical workers in leading higher educational institutions and scientific institutions abroad " was adopted on April 13, 2011 [6]. The Order of the Ministry of Education of Russia "On Approval of the Approximate Provisions on Academic Mobility of Students of Higher Educational Institutions of Russia" defines the general provisions, goals and objectives of academic mobility of students of Russian universities, the legal framework of academic mobility programs for students, organizational support of academic mobility, recognition and recalculation of student learning results at a partner university, duties of partner universities, rights and duties of students at partner universities participating in academic mobility programs, reporting and document preparation procedures for academic mobility programs. The document defines the main types of academic mobility: external academic mobility, training, including practical training of students of higher educational institutions of Russia in higher educational institutions abroad during a certain period; internal academic mobility, training, including internships of students of higher educational institutions of Russia in other higher educational institutions of Russia during a certain period. The main objectives of academic mobility of students of higher educational institutions of Russia are: improving the quality of higher education; increase the effectiveness of research; increasing the competitiveness of university graduates in the Russian and international educational services and labor markets; enrichment of students' individual experience in other models of knowledge creation and dissemination; attraction of the world intellectual potential in the domestic educational process on the basis of bilateral and multilateral agreements between higher education institutions partners; the establishment of internal and external integration links; harmonization of educational standards of partner higher education institutions [4]. Analyzing the content of these documents, we can conclude: despite the progressive tendencies of awareness of the importance of academic mobility, their main weaknesses are the following: lack of specific goals, temporal and quantitative norms, lack of a holistic concept of academic mobility corresponding to the modern realities of international relations - a number of issues require regulation in the field of higher education, recognition of educational documents, regulatory activities of the central education authority of Russia [3]; lack of formulation of clear approaches, goals, sources of funding, tools for the implementation of certain types of academic mobility (inbound, external, multilevel, credit, student mobility, faculty members). Modern Russia remains far behind other European countries members of the European Higher Education Area on the development of academic mobility (inbound and outbound). According to statistics, the inbound mobility of students from countries of the European Higher Education Area is $0.35 \%$ (with an average of $1.72 \%$ in the list of 36 countries) [10]. The inbound mobility of students from countries that are not included in the accreditation is $0.9 \%$ (with an average of $2.25 \%$ in the list of 37 countries). The outbound mobility in the countries of the European Higher Education Area is $0.8 \%$ (with an average of 1.83 in the list of 50 countries), outbound mobility in non-accredited countries is $0.08 \%$ (the average is $0.34 \%$ in the list of from 36 countries: second place from the end after Russia). Such low rates of student mobility characterize the educational sector of Russia as a "closed" system. It is not attractive compared to other European countries, and students do not have the same opportunities to study abroad as in other countries. 
The need to develop inbound mobility is primarily associated with a positive impact on the economy of the host country. According to the report "Immigration of foreign students to EU countries", foreign students contribute to the economy of European countries through tuition, taxes, and participation in the labor market. The study (to which 24 countries were involved) showed economic benefits. This is due to factors such as the number of foreign students in the country, the cost of education, and the level of government subsidies. For example, the UK and Ireland receive the greatest economic benefit from tuition fees. The contribution to the budget from foreign students is equal to 2.6 billion euros in Great Britain, 140 million euros in Ireland. Other EU countries receive the main income from foreign students due to their expenses, living expenses, student tourism. For example, foreign students studying in Italy, bring about 718.5 million euros to the country's economy, which is 0.05 Italy's GNP. According to this study, the number of foreign students in the EU countries increased by $114 \%$ from 2000 to 2010 . The largest number of visas from 2008 to 2011 among the EU countries was issued by the UK, France, Spain, and Italy [9]. The state should promote the increase of academic mobility. It is considered appropriate to use the following activities: the creation of public information centers on academic mobility, the function of which should be to provide clear, reliable information about educational opportunities or scientific activities abroad. An example of such information center is the EURAXESS network created by the European Union, which provides information on proposals for researchers and teachers in the European labor market. In our opinion, the creation of portals for teaching staff and students will be able to significantly increase the level of academic mobility - internal and external; improvement and use of mutual recognition tools - ECTS, supplement to the diploma of the European sample; financial incentives. We consider it appropriate to allocate a separate budget line to stimulate academic mobility; the establishment of a system of credits and loans; support for students who choose programs based on national interests. The strategic direction of development of Russia is the information technology sector. Therefore, credit mobility will allow future professionals to produce products that are competitive in the global market. This will improve the image of the country because it is able to provide quality services or encourage external investors; stimulating in-depth study of foreign languages for viewing time standards, introducing new approaches, providing opportunities for preparing for international exams in a foreign language - FCE, CAE, IELTS, TOEFL, etc. Teaching some courses in a foreign language - the creation of a so-called foreign environment; determining the geopolitical focus - countries with which there are close political and linguistic ties, and assisting in choosing a university for credit mobility in these countries (effective from the point of view of strengthening intergovernmental ties, for example, creating cooperatives); introduction of specific indicators for inbound and outbound mobility; the need to establish the volume of academic mobility, appropriate from a methodological point of view. The question of the minimum amount of credit mobility, which will be sufficient to achieve the mobility goals, is unresolved. For example, mobility, during which the student will receive one loan is now possible. Such a period is too short to gain knowledge and expanding representations in another culture; transfer of programs to other countries - the provision of study programs on the basis of universities abroad in cooperation with these universities. Universityowner of the program is fully responsible for the quality of higher education.

This method will increase the level of entrance academic mobility by attracting foreign students. The success of this method depends on: the correct results of a marketing research aimed at identifying the demand for education in individual countries of the world; development of the organizational structure of the program performed on the basis of a foreign university; program content that meets the demand of foreign students; written criteria for choosing partner universities for the implementation of university programs (resource, material and technical equipment, human resources, etc.). Language is an important factor for the correct pricing policy for educational services provided by the university. According to the OECD, countries whose speech is widespread attract more students. More and more countries in the world (with the exception of Southern Europe, Austria, Belgium, and the Russian Federation) offer programs in English. Teaching individual programs in English (or German) should be a tool to attract students in Russia. Therefore, it is necessary to introduce programs to improve the skills of teachers, their learning a foreign language for teaching. The reputation of the educational institution is becoming increasingly important, as evidenced by the place of universities in the international ranking. It is necessary to analyze the criteria affecting the location of the university in the ranking and take them into account in the process of reforming the higher education system as a whole and in the work of individual educational institutions. It is interesting to observe the distribution of students depending on the disciplines. The proportions of foreign applicants choosing one or another discipline as a whole coincide with the proportions of the total number of applicants choosing these disciplines. An example is the disciplines related to the social sciences, business, and law. However, the number of foreign students studying medicine, science, art, and humanities is slightly higher compared with the total number of students. In addition, a higher concentration of students is observed in separate directions in some countries. For example, $74.1 \%$ and $72.6 \%$ of foreign students study social sciences, business and law in Cyprus and Liechtenstein, compared with an average of $34.71 \%$ in other European countries. A large number of students study medicine in the countries of Central and Eastern Europe and in the French-speaking part of Belgium than in other European countries. The percentage of students studying engineering, manufacturing, and construction in Finland, Sweden, and Liechtenstein is higher compared to other European countries. Such fluctuations are caused by certain factors: the design of the course, the availability of programs in English, the lack of a sufficient number of programs in this direction in the country from which the 
students came [11]. These examples show: an analysis of the competitive advantages of the national higher education system, determining the geopolitical orientation of a marketing company, analyzing the needs of applicants in a selected region, developing products aimed at meeting the demand of a foreign target audience, are an effective tool for expanding entrance mobility. International accreditation of institutions demonstrating the intention to confirm the quality of programs and their compliance with the standards developed by the professional international community can be an additional step to confirm the quality of a higher education institution. Carrying out this procedure is a voluntary decision of universities, and the state can facilitate the involvement of universities in the international accreditation process through the development of regulatory mechanisms for recording the results of international accreditation by the National Agency for Higher Education Quality Assurance.

\section{Conclusion}

Thus, the concept of academic mobility captures almost all the components of the organizational and methodological mechanism of state management of the system of higher education in Russia since it envisages the ultimate goal of creating joint qualifications, standards, and levels. The state should stimulate academic mobility using tools and levers to increase it. Getting the academic staff and students of international experience and raising the status of universities in the world arena is extremely important, given the European vector of development of our state. Meanwhile, the effect of academic mobility on the country's economy should not be underestimated. On the one hand, mobility is an important source of budget replenishment, but on the other, it can lead to problems of the outflow of valuable personnel abroad. Therefore, an adequate state educational policy is necessary to minimize risks and introduce effective mechanisms for increasing academic mobility.

\section{References}

1. A. Courtois, From 'academic concern' to work readiness: student mobility, employability and the devaluation of academic capital on the year abroad, Brit. J. Soc. of Educ., 40 (2), 190-206 (2019).

2. K. Nilemar, L Brown, Academic mobility and cultural change, J. Further and High. Educ., 43 (1), 89-100 (2019).

3. G. Kabanbayeva, M. Gureva, P. Bielik, G. Ostasz Academic mobility and financial stability: A case of Erasmus student exchange program. J. Int. Stud., 12 (1) 324-337 (2019).

4. P. Siekierski, M.C. Lima, F.M. Borini, R.M. Pereira, International academic mobility and innovation: a literature review, J. Gl. Mob., 6 (3-4), 285-298 (2018).

5. S. Ghosh, S.K. Ghosh, Exploring the association between mobility behaviours and academic performances of students: a context-aware traj-graph
(CTG) analysis. Prog. in Artificial Intelligence, 7 (4) 307-326 (2018).

6. R.J. Leemann, Free movement of people and capital and the standard of transnational academic mobility: Principles of governance in the European Research Area, Eu. Educ. Res. J., 17 (6), 857-876 (2018).

7. E. Camino-Esturo, Ecologies and interculturalities in the university: The dialogue of knowledge in the international academic mobility, Utopia y Praxis Latinoamericana, 23 (83), 195-209 (2018).

8. J. Gerhards, S. Hans, D. Drewski, Global inequality in the academic system: effects of national and university symbolic capital on international academic mobility, High. Educ., 76 (4), 669-685 (2018).

9. J.G. Enriquez, The Importance of Academic Mobility: The Erasmus + Program, IT Pro., 20 (5), № 8509532 79-82 (2018).

10. S.'Bedenlier, The Impact of my Work would be Greater here than there': Implications of the International Mobility of Colombian Academics, Res. in Comp. and Int. Educ., 13 (3), 378-396 (2018).

11. P. Siekierski, M.C. Lima., F.M., Borini, International Mobility of Academics: Brain Drain and Brain Gain, Eu. Mngm. Rev., 15 (3), 329-339 (2018).

12. L. Morley, N. Alexiadou, S. Garaz, J. GonzálezMonteagudo, M. Taba, Internationalisation and migrant academics: the hidden narratives of mobility, High. Educ., 76 (3), 537-554 (2018).

13. Lee J.T., A. Kuzhabekova, Reverse flow in academic mobility from core to periphery: motivations of international faculty working in Kazakhstan, High. Educ., 76 (2), 369-386 (2018).

14. P. Mählck, Vulnerability, gender and resistance in transnational academic mobility, Tertiary Educ. and Mngm., 24 (3), 254-265 (2018).

15. Kaiser U., Kongsted H.C., Laursen K., Ejsing A.-K., Experience matters: The role of academic scientist mobility for industrial innovation, Strat. Mngm. J., 39 (7), 1935-1958 (2018).

16. H. Horta, J. Jung, J.M. Santos, Effects of mobilities on the research output and its multidisciplinarity of academics in Hong Kong and Macau: An exploratory study, High. Educ. Qtly., 72 (3), 250-265 (2018).

17. K. Petzold, H. Bucher, The Academic Mobility Regime: Analysing Perceptions of Students and Academic Staff, Int. Rev. Soc. Res., 8 (1), 98-108 (2018).

18. W. Kębłowski, D. Bassens, "All transport problems are essentially mathematical": The uneven resonance of academic transport and mobility knowledge in Brussels, Urban Geo., 39 (3), 413-437 (2018).

19. H. Jöns, Boundary-crossing academic mobilities in glocal knowledge economies: new research agendas based on triadic thought, Glob. Soc. and Educ., 16 (2), 151-161 (2018).

20. M. Engeler, Between afropolitans and new sankaras class mobility and the reproduction of academics in Burkina Faso, Focaal, 2018 (80), 77-90 (2018). 
21. T.W. Yambo, Academic Progression in Nursing Education: Advancing Seamless Educational Mobility, Nurse Educator, 43 (2), 60-62 (2018).

22. A. Toader, J. Dahinden, Family configurations and arrangements in the transnational mobility of earlycareer academics: Does gender make twice the difference? Migration Let., 15 (1), 67-84 (2018).

23. M. Milosz, E. Milosz, The Perception of the OneSemester International Academic Mobility
Programme by Students of Computer Science, Adv. Int. Syst. and Comp., 715, 305-314 (2018).

24. S. Wang, N.V. Gorbunova, A.R. Masalimova, J. Sergeeva, M.G. Bírová, Formation of academic mobility of future foreign language teachers by means of media education technologies, Eurasia J. Math., Sci. Tech. Educ., 14 (3), 959-976 (2018). 